\title{
Analisis Kualitas Layanan Website E-Commerce Bukalapak Terhadap Kepuasan Pengguna Mahasiswa Universitas Bina Darma Menggunakan Metode Webqual 4.0
}

\author{
Adellia $^{1}$, Leon Andretti Abdillah*2 \\ 1,2Information System Departement, Bina Darma University, Palembang, Indonesia \\ Email: ${ }^{1}$ Adellia.151410308@gmail.com, ${ }^{2}$ leon.abdilah@binadarma.ac.id
}

\begin{abstract}
Abstrak
Pertumbuhan teknologi baru, memotivasi beberapa pemasaran produk dilakukan secara online.Faktor yang mendukung perkembangan online salah satunya adalah situs jual beli online (E-Commerce). "Faktor-faktor pendukung E-Commerce salah satunya dengan menggunakan situs web. Website atau juga biasa disebut web merupakan salah satu bentuk media yang dapat diartikan suatu kumpulan-kumpulan halaman yang menampilkan berbagai macam informasi teks, data,gambar diam ataupun bergerak, data animasi,suara,video, baik itu yang bersifat statis maupun dinamis. Perusahaan E-Commerce berinteraksi dengan konsumen melalui web salah satunya adalah website Bukalapak yang merupakan penyedia situs online membeli dan menjual produk yang akan dipasarkan. Untuk mengetahui kualitas sebuah website maka perlu dilakukan pengukur.Dengan melakukan pengukuran kualitas suatu website dapat diketahui persepsi pengguna terhadap website tersebut. Dalam penelitian ini menggunakan metode Webqual 4.0 yang terdiri dari 3 (tiga) dimensi yaitu kegunaan,kualitas informasi dan kualitas interaksi terhadap kepuasan pengguna. Data yang digunakan adalah data primer yang merupakan sumber data yang diperoleh langsung dari sumber asli dengan menyebar kuesioner.Data yang didapat keseluruhan berjumlah 104 responden. Responden dalam penelitian ini adalah Mahasiswa Universitas Bina Darma yang diharapkan dapat memberikan penilaian secara obyektif terhadap website yang akan dianalisis.
\end{abstract}

Keywords: E-Commerce, Kuesioner, SPSS, Website, WebQual 4.0

\section{PENDAHULUAN}

Teknologi informasi (TI) dan komunikasi semakin berkembang setiap waktunya, diantarannya adalah kemunculan internet dan website, selain karena aksesnya yang mudah dan dapat digunakan dimana saja dan kapan saja oleh semua kalangan, internet dan website juga merupakan media yang 


\section{Journal of Software Engineering Ampera}

Vol. 1, No. 3, October 2020 e-ISSN: 2775-2488

https://journal-computing.org/index.php/journal-sea/index

paling up-to-date mengenai informasi. Hingga kini internet telah menjadi gaya hidup bagi sebagian penduduk di dunia, termasuk Indonesia. Dengan terus meningkatnya pengguna internet ini mengindikasikan semakin banyaknya aktifitas online, khususnya pada bidang bisnis. Salah satu tandanya adalah dengan semakin banyaknya pengguna yang melakukan transaksi jual beli online (e-commerce).

E-commerce Indonesia adalah salah satu yang paling banyak dibicarakan ruang didunia startup teknologi Asia Tenggara, bagian ini melibatkan 3 (tiga) layanan komputasi awan (belanja situs online) dibidang e-commerce di Indonesia, seperti: 1)Tokopedia, 2)Bukalapak, dan 3)OLX (Abdillh \& L.A, 2017). Bukalapak adalah salah satu pasar online terkemuka di Indonesia. Sama seperti situs layanan jual beli sarana jual beli dari konsumen ke konsumen. Pengguna e-commerce diberikan kesempatan yang sedikit untuk mengetahui kualitas produk dan melakukan pengujian terhadap produk yang diinginkan melalui media website. Ketika pengguna melakukan pembelian dari website pemasaran yang tidak dikenal, konsumen tidak dapat mengetahui kualitas barang dan jasa yang ditawarkan. Oleh karena itu, salah satu faktor pendukung yang mendorong konsumen melakukan kegiatan e-commerce adalah website. Keberhasilan website dapat diukur dengan melakukan analisis kualitas website.

Salah satu metode yang digunakan untuk melakukan analisis kualitas website adalah metode WebQual. Kualitas e-commerce ditentukan oleh nilai tambah yang diberikan pada produk atau jasa dengan cara mengintegrasikan beberapa komponen dari sumber-sumber yang berbeda seperti interaksi pengguna dan kualitas layanan pada e-commerce itu sendiri, Informasi, interaksi pengguna dan kualitas layanan saat ini merupakan faktor-faktor yang mempengaruhi ke-efektif-an dari sebuah website secara signifikan. Dengan mempertimbangkan faktor-faktor tersebut, para pelaku e-commerce dapat memahami apa yang dibutuhkan oleh pelanggan. WebQual merupakan salah satu metode atau teknik pengukuran kualitas website. Metode WebQual memiliki 3 (tiga) variabel yang dapat diukur dalam menentukan kualitas website yaitu kegunaan, kualitas informasi dan kualitas interaksi layanan. Sebuah website dikatakan baik apabila nilai kualitasnya baik, yaitu dengan melihat hasil dari nilai perhitungan Webqual Index.

Berdasarkan pembahasan diatas maka penulis tertarik untuk melakukan penelitian skripsi agar proses tersebut berjalan dengan lancar. Dengan 


\section{Journal of Software Engineering Ampera}

Vol. 1, No. 3, October 2020 e-ISSN: 2775-2488

https://journal-computing.org/index.php/journal-sea/index

memperhatikan uraian tersebut, maka penelitian skrispsi ini berjudul "Analisis Kualitas Layanan Website E-Commerce Bukalapak Terhadap Kepuasan Pengguna Mahasiswa Universitas Bina Darma Menggunakan Metode WebQual 4.0".Penelitian ini menggunakan sebuah model sebagai kerangka pemikiran teoritis yaitu WebQual. Berdasarkan uraian sebelumnya, maka kerangka pemikiran yang menggambarkan hubungan antara konstruk yang akan di uji sebagai berikut :

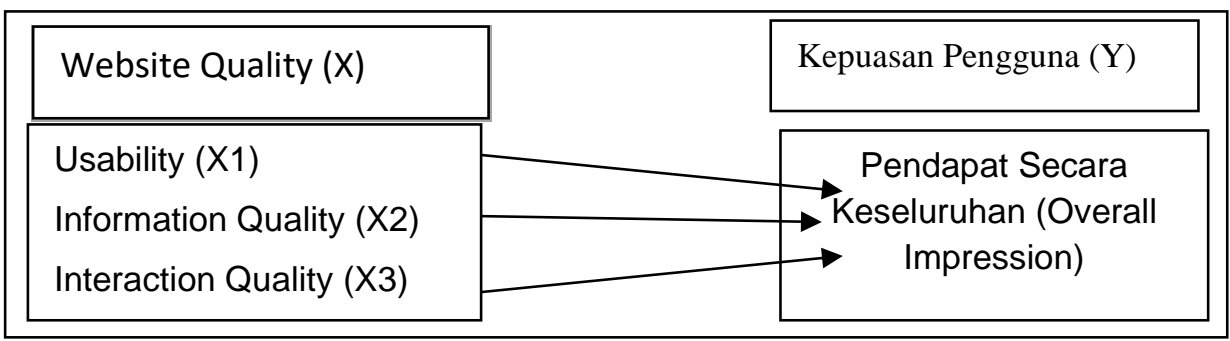

Gambar 1. Kerangka pemikiran

Ketiga variabel bebas terdiri dari kegunaan, kualitas informasi dan interaksi layanan secara bersamaan memberikan pengaruh positif terhadap kepuasan pengguna yang merupakan variabel terikat. Sedangkan kotak Kepuasan Pengguna (Y) menjelaskan dari ketiga variabel bebas terdiri dari kegunaan, kualitas informasi dan interaksi layanan apakah masing-masing memberikan pengaruh positif terhadap kepuasan pengguna yang merupakan variabel terikat. Hipotesis pada penelitian ini, untuk mengetahui apakah variabel kegunaan, variabel kualitas informasi daan variabel interaksi layanan berpengaruh terhadap kepuasan pengguna. Hipotesis dalam penelitian ini dapat dirumuskan sebagai berikut:

1) H1 : Terdapat pengaruh dimensi Usability website Bukalapak terhadap kepuasan pengguna.

2) H2 : Terdapat pengaruh dimensi Information Quality website Bukalapak terhadap kepuasan pengguna.

3) H3 : Terdapat pengaruh dimensi Service Interaction Quality website Bukalapak terhadap kepuasan pengguna.

\section{METODE PENELITIAN}

\subsection{Populasi dan Teknik Pengambilan Sampel}

Populasi adalah wilayah generalisasi yang terdiri atas: obyek/subyek yang mempunyai kuanitas dan karakteristik tertentu yang ditetapkan oleh peneliti untuk dipelajari dan kemudian ditarik kesimpulannya (Sugiyono, 2017). 


\section{Journal of Software Engineering Ampera}

Vol. 1, No. 3, October 2020 e-ISSN: 2775-2488

https://journal-computing.org/index.php/journal-sea/index

Peneliti menetapkan populasi penelitian adalah Mahasiswa Bina Darma yang berjumlah 6310 mahasiswa di Universitas Bina Darma. Sampel adalah bagian dari jumlah dan karakteristik yang dimiliki oleh populasi. Bila populasi besar, dan peneliti tidak mungkin mempelajari semua yang ada pada populasi besar, misalnya karena keterbatasan dana, tenaga dan waktu, maka peneliti dapat menggunakan sampel yang diambil dari populasi itu (Sugiyono, 2017). Jenis pengambilan sampel yang digunakan dalam penelitian ini adalah Random Sampling dimana teknik penentuan sampel dilakukan secara acak.

\subsection{Instrument Penelitian}

Instrument penelitian adalah alat yang dimaksudkan untuk mengukur dan mengetahui tingkat validalitas (kesahihan) dan reliabilitas (keterandalan), tingkat kesukaran dan pembeda instrument penelitian (SUPARDI, 2014). Pada penelitian ini, instrument yang digunakan pada penelitian ini berupa kuesioner berupa pertanyaan yang akan dijawab oleh responden, untuk penyusunan kuesionernya menggunakan skala likert. Kuesiner penelitian ini akan diberikan kepada respoden Mahasiswa Bina Darma Palembang. Kuesioner yang disebarkan tersebut benar-benar dapat mengukur yang diinginkan penelitian untuk diukur, sehingga harus valis dan andal. Maka diperlukannya uji validitas dan uji reliabilitas akan pernyataan yang ada di kuesioner tersebut, agar data yang akan diolah tidak memberikan hasil yang menjerumuskan peneliti.

\subsection{Uji Validalitas}

Uji validitas digunakan untuk mengetahui seberapa tepat suatu alat ukur mampu melakukan fungsi. Uji validitas berarti instrumen yang digunakan dapat mengukur apa yang diukur. Biasanya digunakan dengan menghitung korelasi antara setiap skor butir instrumen dengan skor total (Sugiyono, Statistika untuk Penelitian, 2014). Validitas menunjukan sejauh mana alat ukur itu dapat mengukr apa yang diukur. Valid tidaknya suatu alat ukur tergantung pada mampu atau tidaknya alat ukur tersebut mencapai yang dikehendakinya dengan tepat. Karena suatu alat ukur tyang kurang valid berarti tingkat validnya rendah. Pengukuran validitas dilakukan dengan analisis korelasi Product Moment dengan kriteria pengambilan keputusan sebagai berikut:

1) Apabila $r$ hitung $>r$ tabel maka instrumen dinyatakan valid, serta sebaliknya bila $r$ hitung $<r$ tabel maka instrumen dinyatakan tidak valid. 


\section{Journal of Software Engineering Ampera}

Vol. 1, No. 3, October 2020 e-ISSN: 2775-2488

https://journal-computing.org/index.php/journal-sea/index

2) Apabila probabilitas (sig.2 tailed) $<0.05$ maka instrumen dinyatakan valid, serta sebaliknya bila probabilitas (sig2. Tailed) $>0.05$ maka instrumen dinyatakan tidak valid.

\subsection{Uji Reliabilitas}

Reliabilitas berkenaan dengan derajat konsistensi dan stabilitas data atau temuan. Dalam pandangan positivistik kuantitatif, suatu data dikatakan reliabel apabila dua atau lebih peneliti dalam objek yang sama menghasilkan data yang sama, atau peneliti sama dalam waktu berbeda menghasilkan data yang sama, atau sekolompok data bila dipecah menjadi dua menunjukan data yang tidak berbeda (Sugiyono, 2014). Reliabilitas juga menunjukan pada suatu pengertian bahwa suatu alat ukur cukup dipercaya untuk digunakan sebagai alat pengumpul data, karena alat tersebut sudah baik. Untuk mengukur reliabilitas dengan menggunakan uji statistik Alpha Cronbach, variabel dapat dikatakan reliabel jika memberikan nilai a> 0,60.

Tabel 1. Interpementasi Nilai a (Alpha) Terhadap Reliabilitas

\begin{tabular}{ll}
\hline Alpha Alpha & Tingkat Reliabilitas \\
\hline $0,00<r<0,20$ & Kurang Reliabel \\
$0,20<r<0,40$ & Agak Reliabel \\
$0,40<r<0,60$ & Cukup Reliabel \\
$0,60<r<0,80$ & Reliabel \\
$0,80<r<0,100$ & Sangat Reliabel \\
\hline
\end{tabular}

\subsection{Uji Asumsi Klasik}

Pengujian ini dilakukan untuk mengetahui apakah model estimasi telah memenuhi kriteria ekometrik dalam arti tidak terjadi penyimpangan yang cukup serius dari asumsi-asumsi yang diperlukan (Sugiyono, 2014).

\subsection{Uji Normalitas}

Uji normalitas adalah Alat uji yang digunakan untuk mengetahui apakah dalam sebuah model regresi, nilai residu dari regresi mempunyai distribusi yang normal. Jika distribusi dari nilai-nilai residual tersebut tidak dapat dianggap berdistribusi normal, maka dikatakan ada masalah terhadap asumsi 


\section{Journal of Software Engineering Ampera}

Vol. 1, No. 3, October 2020 e-ISSN: 2775-2488

https://journal-computing.org/index.php/journal-sea/index

normalitas (Santoso S. , 2010).Deteksi dengan melihat penyebaran data (titik) pada sumbu diagonal dari grafik, dengan dasar pengambilan keputusan:

1) Jika data menyebar di sekitar garis diagonal dan mengikuti arah garis diagonal, maka model regresi memenuhi asumsi Normalitas.

2) Jika data menyebar jauh dari garis diagonal dan/atau tidak mengikuti arah garis diagonal, maka model regresi tidak memenuhi asumsi Normalitas.

\subsection{Uji Heteroskedastisitas}

Heteroskedastisitas adalah suatu keadaan yang menunjukan bahwa variabel tidak sama (konstan) antara pengamatan satu dengan pengamatan lainnya. Untuk mendeteksi ada atau tidak adanya heteroskedastisitas terdapat beberapa uji statistik yang dapat digunakan diantarannya: uji gletjer, uji park, uji white dan uji scatterplot (Wijaya, 2009) dalam jurnal (Hanifa, 2017).

Uji heteroskedastisitas digunakan untuk melihat apakah terdapat ketidaksamaan varians dari residual satu ke pengamatan ke pengamatan yang lain. Model regresi yang memenuhi persyaratan adalah di mana terdapat kesamaan varians dari residual satu pengamatan ke pengamatan yang lain tetap atau disebut homoskedastisitas. Untuk mengetahui apakah terjadi atau tidak terjadi heteroskedastisitas dalam suatu model regresi yaitu dengan melihat grafik scatterplot (Ghozali, 2012).

\subsection{Uji Regresi Berganda}

Analisis regresi berganda digunakan oleh peneliti, bila peneliti bermaksud meramalkan bagaimana keadaan (naik turunnya) variabel dependen (kriterium), bila dua atau lebih variabel independen sebagai faktor prediktor dimanipulasi (dinaik turunkan nilainnya). Jadi analisis regresi ganda akan dilakukan bila jumlah variabel independennya minimal 2. Persamaan regresi untuk dua prediktor adalah:

$$
Y=a+b_{1} X_{1}+b_{2} X_{2}
$$

Persamaan regresi untuk tiga prediktor adalah :

$$
Y=a+b_{1} X_{1}+b_{2} X_{2}+b_{3} X_{3}
$$




\section{Journal of Software Engineering Ampera}

Vol. 1, No. 3, October 2020 e-ISSN: 2775-2488

https://journal-computing.org/index.php/journal-sea/index

Persamaan regresi untuk $n$ prediktor adalah :

$$
Y=a+b_{1} X_{1}+b_{2} X_{2}+\ldots \ldots+b_{n} X_{n}
$$

Untuk bisa membuat ramalan melalui regresi, maka data setiap variabel harus tersedia. Selanjutnya berdasarkan data itu peneliti harus dapat menemukan persamaan melalui perhitungan (Sugiyono, 2017) .

\subsection{Uji Hipotesis}

Uji hipotesis digunakan untuk mengetahui apakah di antara variabel ada yang mempengaruhi pengaruh sehingga harus dilakukan pengujian hipotesis (Ghozali, 2012). Hipotesis dalam penelitian ini akan diuji dengan menggunakan analisis jalur (path analysis). Analisis jalur merupakan suatu teknik untuk menganalisis hubungan sebab akibat yang terjadi pada regresi berganda jika variabel bebasnya mempengaruhi variabel tergantung tidak hanya secara langsung, tetapi juga secara tidak langsung. Pengujian hipotesis digunakan alat uji statistik path analysis, yakni untuk mengkaji pengaruh secara simultan maupun parsial antara variabel independen terhadap variabel dependen. Untuk pengujian hipotesis, dengan menghitung besarnya parameter struktural sesuai dengan hipotesis yang diajukan. Dari seluruh variabel yang akan dianalisis dalam penelitian ini, secara konseptual dapat digambarkan dalam diagram jalur atau path analysis.

\subsubsection{Uji F}

Uji Statistik F pada dasarnya menunjukkan apakah semua variabel independen atau variabel bebas yang dimasukkan dalam model mempunyai pengaruh secara bersama-sama terhadap variabel dependen atau variabel terikat (Ghozali, 2012). Untuk menguji hipotesis ini digunakan statistik F dengan kriteria pengambilan keputusan sebagai berikut:

1) Jika nilai $\mathrm{F}$ lebih besar dari 4 maka $\mathrm{HO}$ ditolak pada derajat kepercayaan 5\% dengan kata lain kita menerima hipotesis alternatife, yang menyatakan bahwa semua variabel independen secara serentak dan signifikan mempengaruhi variabel dependen.

2) Membandingkan nilai $F$ hasil perhitungan dengan $F$ menurut tabel. Bila nilai Fhitung lebih besar dari pada nilai Ftabel, maka Ho ditolak dan menerima $\mathrm{Ha}$. 


\section{Journal of Software Engineering Ampera}

Vol. 1, No. 3, October 2020 e-ISSN: 2775-2488

https://journal-computing.org/index.php/journal-sea/index

\subsubsection{Uji T}

Uji beda t-test digunakan untuk menguji seberapa jauh pengaruh variabel independen yang digunakan dalam penelitian ini secara individual dalam menerangkan variabel dependen secara parsial (Ghozali, 2012). Dasar pengambilan keputusan digunakan dalam uji t adalah sebagai berikut:

1) 1. Jika nilai probabilitas signifikansi $>0,05$, maka hipotesis ditolak. Hipotesis ditolak mempunyai arti bahwa variabel independen tidak berpengaruh signifikan terhadap variabel dependen.

2) Jika nilai probabilitas signifikansi $<0,05$, maka hipotesis diterima. Hipotesis tidak dapat ditolak mempunyai arti bahwa variabel independen berpengaruh signifikan terhadap variabel dependen.

\section{HASIL DAN PEMBAHASAN}

Responden dalam penelitian ini adalah mahasiswa Universitas Bina Darma dengan jumlah data yang didapat sebanyak 104 Responden. Berikut ini akan dijelaskan karakteristik responden pengguna website e-commerce Bukalapak. Berikut ini adalah hasil dari pengujian yang telah dilakukan:

\subsection{Ujii Validitas dan Relibilitas}

\subsubsection{Uji Validitas}

Uji validitas dilakukan dengan memasukan data pada program SPSS versi 23. Uji validitas dilakukan dengan menggunakan analisis product moment/pearson pada masing-masing variabel yaitu Kualitas Kegunaan (X1), Kualitas Informasi (X2), Kualitas Interaksi Layanan (X3), dan Kepuasan Pengguna (Y) melalui program SPSS.

\section{Kualitas Kegunaaann (X1)}

Tabel 1. Validitas Kualitas Kegunaan (X1)

\begin{tabular}{llllll}
\hline Item Pertanyaan & $\mathbf{r}$ hitung & $\mathbf{r}$ tabel & Kondisi & Sig & Kesimpulan \\
\hline USA01 & 0,657 & 0,254 & $r$ hitung $>r$ tabel & 0,000 & Valid \\
USA02 & 0,714 & 0,254 & $r$ hitung $>r$ tabel & 0,000 & Valid \\
USA03 & 0,704 & 0,254 & $r$ hitung $>r$ tabel & 0,000 & Valid \\
USA04 & 0,719 & 0,254 & $r$ hitung $>r$ tabel & 0,000 & Valid \\
USA05 & 0,694 & 0,254 & $r$ hitung $>r$ tabel & 0,000 & Valid \\
\hline
\end{tabular}




\section{Journal of Software Engineering Ampera}

Vol. 1, No. 3, October 2020 e-ISSN: 2775-2488

https://journal-computing.org/index.php/journal-sea/index

\begin{tabular}{llllll}
\hline USA06 & 0,653 & 0,254 & $r$ hitung $>r$ tabel & 0,000 & Valid \\
USA07 & 0,750 & 0,254 & $r$ hitung $>r$ tabel & 0,000 & Valid \\
USA08 & 0,592 & 0,254 & $r$ hitung $>r$ tabel & 0,000 & Valid \\
\hline
\end{tabular}

2. Kualitas Informasi (X2)

Tabel 2. Validitas Kualitas Informasi (X2)

\begin{tabular}{llllll}
\hline Item Pertanyaan & $r$ hitung & $r$ tabel & Kondisi & Sig & Kesimpulan \\
\hline INF01 & 0,572 & 0,254 & $r$ hitung $>r$ tabel & 0,000 & Valid \\
INF02 & 0,753 & 0,254 & $r$ hitung $>r$ tabel & 0,000 & Valid \\
INF03 & 0,761 & 0,254 & $r$ hitung $>r$ tabel & 0,000 & Valid \\
INF04 & 0,704 & 0,254 & $r$ hitung $>r$ tabel & 0,000 & Valid \\
INF05 & 0,730 & 0,254 & $r$ hitung $>r$ tabel & 0,000 & Valid \\
INF06 & 0,705 & 0,254 & $r$ hitung $>r$ tabel & 0,000 & Valid \\
INF07 & 0,684 & 0,254 & $r$ hitung $>r$ tabel & 0,000 & Valid \\
\hline
\end{tabular}

3. Kualitas Interaksi Layanan (X3)

Tabel 3. Validitas Kualitas Interaksi Layanan (X3)

\begin{tabular}{llllll}
\hline Item Pertanyaan & $r$ hitung & $\mathbf{r}$ tabel & Kondisi & Sig & Kesimpulan \\
\hline SERV01 & 0,742 & 0,254 & $r$ hitung $>r$ tabel & 0,000 & Valid \\
SERV02 & 0,807 & 0,254 & $r$ hitung $>r$ tabel & 0,000 & Valid \\
SERV03 & 0,756 & 0,254 & r hitung $>r$ tabel & 0,000 & Valid \\
SERV04 & 0,752 & 0,254 & r hitung $>r$ tabel & 0,000 & Valid \\
SERV05 & 0,770 & 0,254 & r hitung $>r$ tabel & 0,000 & Valid \\
SERV06 & 0,663 & 0,254 & r hitung $>r$ tabel & 0,000 & Valid \\
SERV07 & 0,676 & 0,254 & r hitung $>r$ tabel & 0,000 & Valid \\
\hline
\end{tabular}

4. Overall Impression $(Y)$

Tabel 4. Validitas Overall Impression

\begin{tabular}{llllll}
\hline Item Pertanyaan & $r$ hitung & $r$ tabel & Kondisi & Sig & Kesimpulan \\
\hline IOI01 & 1000 & 0,254 & $r$ hitung $>r$ tabel & 0,000 & Valid \\
\hline
\end{tabular}

Berdasarkan tabel 4 diatas tersebut, dapat disimpulkan bahwa setiap variabel pertanyaan memiliki nilai $r$ hitung (nilai pada Corrected Item Total Corelation) lebih besar dari nilai $r$ tabel (didapat dari nilai-nilai tabel $r$ product moment) dan nilai positif maka butir pertanyaan atau indikator tersebut dinyatakan valid". 


\section{Journal of Software Engineering Ampera}

Vol. 1, No. 3, October 2020 e-ISSN: 2775-2488

https://journal-computing.org/index.php/journal-sea/index

\subsubsection{Uji Reliabilitas}

Tabel 5. Uji Reliabilitas

\begin{tabular}{llll}
\hline Variabel & Cronbach's Alpha $(r$ hitung) & Kondisi & Simpulan \\
\hline Variabel X1 & 0,839 & $r$ hitung $>r$ tabel & Reliabel \\
Variabel X2 & 0,827 & $r$ hitung $>r$ tabel & Reliabel \\
Variabel X3 & 0,861 & $r$ hitung $>r$ tabel & Reliabel \\
Variabel Y & 1,000 & $r$ hitung $>r$ tabel & Reliabel \\
\hline
\end{tabular}

Berdasarkan tabel-tabel diatas, dapat diketahui bahwa variabel Usability, Information Quality, Interaction Quality dan Overall Impression menyatakan reliabel. Hal ini dapat dilihat dari nilai Cronbach's Alpha r hitung > dari $r$ tabel $(0,06)$.

\subsection{Uji Asumsi Klasik}

Uji Asumsi Klasik adalah pengujian terhadap model regresi untuk menghindari adanya penyimpangan pada model regresi dan untuk mendapatkan model regresi yang lebih akurat. Dalam penelitian ada 2 pengujian asumsi klasik yaitu uji normalitas dan uji heteroskedastisitas.

1. Uji Normalitas

Uji normalitas adalah pengujian tentang kenormalan distribusi data. Uji ini merupakan pengujian yang paling banyak dilakukan untuk analisis statistik parametrik.Dengan menggunakan metode grafik maka dapat dilihat penyebaran data pada sumber diagonal pada grafik normal P-P Plot of regression standarized residual. Dari grafik terlihat bahwa nilai plot P-P terletak disekitar garis diagonal, plot P-P tidak menyimpang jauh dari garis diagonal sehingga dapat diartikan bahwa distribusi data normal.regresi dapat dilihat pada gambar.

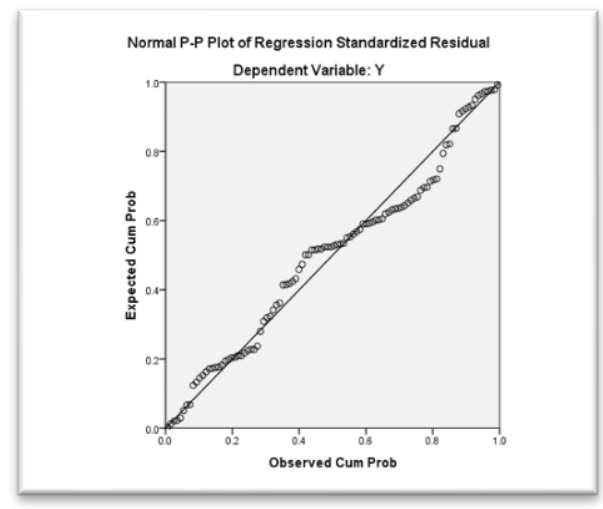

Gambar 2. Uji Normalitas 


\section{Journal of Software Engineering Ampera}

Vol. 1, No. 3, October 2020 e-ISSN: 2775-2488

https://journal-computing.org/index.php/journal-sea/index

2. Uji Heteroskedastisitas

Heteroskedastisitas adalah suatu keadaan yang menunjukan bahwa variabel tidak sama (konstan) antara pengamatan satu dengan pengamatan lainnya. Untuk mendeteksi ada atau tidak adanya heteroskedastisitas terdapat beberapa uji statistik yang dapat digunakan diantarannya: uji gletjer, uji park, uji white dan uji scatterplot (Wijaya, 2009) dalam jurnal (Hanifa, 2017).

Tabel 6. Uji Heteroskedastisitas

\begin{tabular}{|c|c|c|c|c|c|c|}
\hline \multicolumn{7}{|c|}{ Coefficients $^{a}$} \\
\hline \multirow{2}{*}{\multicolumn{2}{|c|}{ Model }} & \multicolumn{2}{|c|}{$\begin{array}{l}\text { Unstandardized } \\
\text { Coefficients }\end{array}$} & $\begin{array}{l}\text { Standardized } \\
\text { Coefficients }\end{array}$ & \multirow[t]{2}{*}{$\mathrm{T}$} & \multirow[t]{2}{*}{ Sig. } \\
\hline & & \multirow{2}{*}{$\begin{array}{l}\text { B } \\
- \\
, 199\end{array}$} & \multirow{2}{*}{$\begin{array}{l}\text { Std. } \\
\text { Error } \\
, 311\end{array}$} & \multirow[t]{2}{*}{ Beta } & & \\
\hline \multirow[t]{4}{*}{1} & (Constant) & & & &,- 641 & ,523 \\
\hline & $\mathrm{X} 1$ & ,012 & 011 & , 134 & 1,044 & ,299 \\
\hline & $x 2$ & $\begin{array}{l}- \\
, 004\end{array}$ & ,014 &,- 037 &,- 265 & ,791 \\
\hline & X3 & 012 & ,013 & ,123 & ,981 & 329 \\
\hline
\end{tabular}

\subsection{Hasil Regresi Berganda}

Berdasarkan perhitungan regresi berganda antara variabel Webqual 4.0 yaitu Usability, Information Quality, Interaction Quality dan Overall Impression, dengan menggunakan program SPSS 23, diperoleh hasil sebagai berikut.

Tabel 7 Hasil Uji Regresi

\begin{tabular}{|c|c|c|c|c|c|c|c|c|}
\hline \multicolumn{9}{|c|}{ Coefficients $^{a}$} \\
\hline \multirow{2}{*}{\multicolumn{2}{|c|}{ Model }} & \multicolumn{2}{|c|}{$\begin{array}{l}\text { Unstandardi } \\
\text { zed } \\
\text { Coefficients }\end{array}$} & \multirow{2}{*}{$\begin{array}{l}\text { Standardi } \\
\text { zed } \\
\text { Coefficie } \\
\text { nts } \\
\text { Beta }\end{array}$} & \multirow[t]{2}{*}{$\mathrm{T}$} & \multirow[t]{2}{*}{ Sig } & \multicolumn{2}{|c|}{$\begin{array}{l}\text { Collinearity } \\
\text { Statistics }\end{array}$} \\
\hline & & $B$ & $\begin{array}{l}\text { Std. } \\
\text { Erro } \\
r\end{array}$ & & & & $\begin{array}{l}\text { Tolera } \\
\text { nce }\end{array}$ & VIF \\
\hline 1 & $\begin{array}{l}\text { (Consta } \\
n t)\end{array}$ & -919 & .485 & & $\begin{array}{l}- \\
1.8\end{array}$ & $\begin{array}{l}.06 \\
1\end{array}$ & & \\
\hline
\end{tabular}




\section{Journal of Software Engineering Ampera}

Vol. 1, No. 3, October 2020 e-ISSN: 2775-2488

https://journal-computing.org/index.php/journal-sea/index

\begin{tabular}{|c|c|c|c|c|c|c|c|}
\hline & & & & 96 & & & \\
\hline $\mathrm{X} 1$ & .068 & .017 & .441 & $\begin{array}{l}3.9 \\
61\end{array}$ & $\begin{array}{l}.00 \\
0\end{array}$ & .587 & $\begin{array}{l}1.7 \\
04\end{array}$ \\
\hline$\times 2$ & $\begin{array}{l}- \\
.005\end{array}$ & .021 & -.030 & $\begin{array}{l}- \\
.24 \\
5\end{array}$ & $\begin{array}{l}.80 \\
7\end{array}$ & .494 & $\begin{array}{l}2.0 \\
23\end{array}$ \\
\hline X3 & .030 & .020 & .167 & $\begin{array}{l}1.5 \\
40\end{array}$ & $\begin{array}{l}.12 \\
7\end{array}$ & .614 & $\begin{array}{l}1.6 \\
27\end{array}$ \\
\hline
\end{tabular}

Dari hasil regresi yang didapat, maka dapat dibuat persamaan regresi linear berganda sebagai berikut:

$Y_{2}=-0,919+0,68 X_{1}+-0,005 X_{2}+0,030+e$

Persamaan regresi tersebut mempunyai arti sebagai berikut :

1) Konstanta yang bernilai negatif sebesar -0,919, menyatakan bahwa jika Usability(X1), Information Quality(X2), dan Interaction Quality(X3) nilainnya adalah 0, maka kepuasan (Y) nilainnya adalah -0,919.

2) Koefisien regresi Usability (X1) sebesar 0,068, hal ini menunjukan jika variabel independen lain nilainya tetap dan Usability mengalami kenaikan 1\%, maka kepuasan mahasiswa (Y) akan mengalami kenaikan sebesar 0,068.

3) Koefisien regresi Information Quality (X2) sebesar -0,005, hal ini menunjukan jika Information Quality (X2)kurang dari 1\% maka Information Quality akan mengalami sebesar -0,005 \%, asumsi variabel lain tetap, koefisien Information Quality bernilai negatif, maka Information Quality mempengaruhi negatif terhadap kepuasan pengguna.

4) Koefisien regresi Interaction Quality sebesar 0,030, hal ini menunjukan jika variabel independen lain nilainnya tetap dan Interaction mengalami kenaikan 1\%, maka kepuasan mahasiswa (Y) akan mengalami kenaikan sebesar 0,030.

\subsection{Hasil Hipotesis}

Untuk mengetahui ada tidaknya pengaruh variabel bebas terhadap variabel terikat, maka dilakukan pengujian terhadap hipotesis yang diajukan dalam penelitian ini. Metode pengujian terhadap hipotesis yang dilakukan dengan pengujian secara simultan dan pengujian secara persial. 


\section{Journal of Software Engineering Ampera}

Vol. 1, No. 3, October 2020 e-ISSN: 2775-2488

https://journal-computing.org/index.php/journal-sea/index

\section{1) Uji F}

Uji hitung atau $(\mathrm{P}<0,05)$ ini bertujuan untuk menguji apakah variabel Webqual (Usability, Information Quality, dan Interaction Quality), mempunyai pengaruh yang signifikan terhadap kepuasan pengguna website Bukalapak di Universitas Bina Darma.

Tabel 8. Tabel $f$

\begin{tabular}{|c|c|c|c|c|c|c|}
\hline \multicolumn{7}{|c|}{ ANOVA $^{a}$} \\
\hline \multicolumn{2}{|c|}{ Model } & Sum of & Df & Mean & $\mathrm{F}$ & Sig. \\
\hline \multirow[t]{3}{*}{1} & Regression & 10.682 & 3 & 3.561 & 12.558 & $.000^{b}$ \\
\hline & Residual & 28.356 & 100 & .284 & & \\
\hline & Total & 39.038 & 103 & & & \\
\hline \multicolumn{7}{|c|}{ a. Dependent Variable: Y } \\
\hline \multicolumn{7}{|c|}{ b. Predictors: (Constant), X3, X1, X2 } \\
\hline
\end{tabular}

uji F digunakan untuk menguji pengaruh variabel independen secara bersamasama terhadap variabel dependen. Taraf signifikan yang digunakan adalah 0,05. Untuk hipotesis yang akan diajukan adalah sebagai berikut:

1) Ho: Variabel kualitas kegunaan (usability), variabel kualitas informasi (information quality) dan variabel kualitas interaksi layanan (service interaction quality) secara bersama-sama tidak berpengaruh terhadap kepuasan pengguna (user satisfaction).

2) $\mathrm{H}_{1}$ : Variabel kualitas kegunaan (usability), variabel kualitas informasi (information quality) dan variabel kualitas interaksi layanan (service interaction quality) secara bersama-sama berpengaruh terhadap kepuasan pengguna (user satisfaction).

Selanjutnya adalah mencari $F$ hitung dan $F$ tabel. Berdasarkan tabel 4.9 Output Regression ANOVA diketahui nilai F hitung sebesar 12,558 dengan nilai signifikan 0,000 . Untuk $F$ tabel dapat dicari dengan melihat pada tabel $F$ dengan signifikansi 0,05 dan menentukan df1 = k-1 atau 3-1 = 2, dan df2 =n-k atau 104-3 = 101 ( $n$-jumlah data; k=jumlah variabel independen). Didapat $F$ tabel adalah sebesar 3,09. Jika apabila $F$ hitung $\leq F$ tabel maka Ho diterima dan apabila $\mathrm{F}$ hitung $\geq \mathrm{F}$ tabel maka $\mathrm{H}_{1}$ ditolak. Dapat diketahui bahwa $\mathrm{F}$ hitung $(12,558)>F$ tabel $(3,09)$, maka Ho ditolak , jadi kesimpulannya yaitu kualitas kegunaan (usability), kualitas informasi (information quality) dan 


\section{Journal of Software Engineering Ampera}

Vol. 1, No. 3, October 2020 e-ISSN: 2775-2488

https://journal-computing.org/index.php/journal-sea/index

kualitas interaksi layanan (interaction quality) secara bersama-sama berpengaruh terhadap kepuasan pengguna.

\section{2) Uji T}

Uji T digunakan untuk menguji pengaruh independen secara persial terhadap variabel dependen. Taraf signifikan yang ditentukan adalah menggunakan nilai 0,05. Berikut adalah perhitungan uji t dari tiap variabel independen:

\section{Kualitas Kegunaan (X1)}

Diketahui t hitung dari kualitas kegunaan adalah 3,961 (pada tabel 4.9 Hasil Uji Regresi), t tabel dapat dicari pada tabel statistik pad signifikansi 0,05/2 = 0,025 (uji 2 sisi) dengan df = n-k-1 atau 104-3-1 = 101 ( $\mathrm{k}$ adalah jumlah variabel independen ). Didapat t tabel sebesar 1,983. Kesimpulan yang dapat diambil apabila $\mathrm{t}$ hitung $\leq \mathrm{t}$ tabel atau $\mathrm{t}$ hitung $\geq \mathrm{t}$ tabel jadi Ho diterima. Apabila $\mathrm{t}$ hitung $>\mathrm{t}$ tabel atau $\mathrm{t}$ hitung $<\mathrm{t}$ tabel jadi Ho ditolak. Dapat diketahui bahwa $t$ hitung $(3,961)>t$ tabel $(1,983)$ jadi Ho ditolak, kesimpulannya yaitu kualitas kegunaan (X1) berpengaruh terhadap kepuasan prngguna $(\mathrm{Y})$.

\section{Kualitas Informasi (X2)}

Diketahui t hitung dari kualitas informasi adalah -0,245 (pada tabel 4.9 Hasil Uji Regresi), t tabel dapat dicari pada tabel statistik pad signifikansi 0,05/2 = 0,025 (uji 2 sisi) dengan df = n-k-1 atau 104-3-1 = 101 ( $\mathrm{k}$ adalah jumlah variabel independen ). Didapat t tabel sebesar 1,983. Kesimpulan yang dapat diambil apabila $\mathrm{t}$ hitung $\leq \mathrm{t}$ tabel atau $\mathrm{t}$ hitung $\geq \mathrm{t}$ tabel jadi Ho diterima. Apabila $\mathrm{t}$ hitung $>\mathrm{t}$ tabel atau $\mathrm{t}$ hitung $<\mathrm{t}$ tabel jadi Ho ditolak. Dapat diketahui bahwa $\mathrm{t}$ hitung $(-0,245)<\mathrm{t}$ tabel $(1,983)$ jadi Ho diterima, kesimpulannya yaitu kualitas Informasi (X2) tidak berpengaruh terhadap kepuasan pengguna $(\mathrm{Y})$.

3. Kualitas Interaksi Layanan (X3)

Diketahui t hitung dari kualitas interaksi layanan adalah 1,540 (pada tabel 4.9 Hasil Uji Regresi), t tabel dapat dicari pada tabel statistik pad signifikansi 0,05/2 = 0,025 (uji 2 sisi) dengan df = n-k-1 atau 104-3-1 = 101 ( $\mathrm{k}$ adalah jumlah variabel independen ). Didapat t tabel sebesar 1,983 . Kesimpulan yang dapat diambil apabila t hitung $\leq \mathrm{t}$ tabel atau $\mathrm{t}$ hitung $\geq \mathrm{t}$ tabel jadi Ho diterima. Apabila $t$ hitung $>\mathrm{t}$ tabel atau $\mathrm{t}$ hitung $<\mathrm{t}$ tabel jadi Ho ditolak. Dapat diketahui bahwa $\mathrm{t}$ hitung $(1,540)<\mathrm{t}$ tabel $(1,983)$ jadi Ho diterima, 


\section{Journal of Software Engineering Ampera}

Vol. 1, No. 3, October 2020 e-ISSN: 2775-2488

https://journal-computing.org/index.php/journal-sea/index

kesimpulannya yaitu kualitas interaksi layanan (X3) tidak berpengaruh terhadap kepuasan pengguna $(\mathrm{Y})$.

Berdasarkan nilai koefisien variabel kualitas kegunaan $(\mathrm{X} 1)$ adalah nilai b $(\mathrm{X} 1)=$ 0,068 , variabel kualitas informasi $(X 2)$ adalah nilai $b(X 2)=-0,005$, dan variabel kualitas interaksi layanan (X3) adalah nilai b (X3) =0,030. Berdasarkan hasil uji t diketahui bahwa variabel kualitas informasi (X2) dan variabel kualitas interaksi layanan (X3) tidak signifikan, maka persamaan regresi linear berganda adalah:

$$
\begin{aligned}
& Y=a+b(X 1)+b(X 2)+b(X 3) \\
& Y=-0,919+0,068(X 1)+-0,005(X 2)+0,030(X 3)
\end{aligned}
$$

Dimana $Y$ adalah variabel defenden yang diramalkan, a adalah konstanta, $b$ $(\mathrm{X} 1), \mathrm{b}(\mathrm{X} 2), \mathrm{b}(\mathrm{X} 3)$ adalah koefisien regresi, sedangkan $\mathrm{X} 1, \mathrm{X} 2, \mathrm{X} 3$ adalah variabel independen. Kesimpulan yang dapat diambil antara lain:

1. Nilai dari variabel kepuasan pengguna $(Y)$ sebesar $-0,919$ berarti jika semua variabel bebas memiliki nilai nol (0) maka nilai variabel kepuasan pengguna $(Y)$ sebesar $-0,919$.

2. Nilai 0,068 dan bertanda positif pada variabel kegunaan (X1) memiliki arti, apabila X1 dinaikan 1 poin maka $Y$ akan naik sebesar 0,068.

3. Nilai $-0,005$ dan bertanda negatif pada variabel kualitas informasi (X2) memiliki arti, apabila X2 diturunkan 1 poin maka $Y$ akan turun sebesar 0,005 .

4. Nilai 0,030 dan bertanda positif pada variabel interaksi layanan (X3) memiliki arti, apabila $\mathrm{X} 3$ dinaikan poin maka $Y$ akan naik sebesar 0,030 .

\section{KESIMPULAN}

Penelitian kualitas website terhadap kepuasan pengguna Mahasiswa Universitas Bina Darma menggunakan metode Webqual 4.0 pada website www.bukalapak.com menghasilkan kesimpulan sebagai berikut:

1) Variabel kualitas kegunaan (Usability) berpengaruh positif dan signifikan terhadap kepuasan pengguna website e-commerce Bukalapak.

2) Variabel kualitas informasi (information quality) berpengaruh negatif terhadap kepuasan pengguna website e-commerce Bukalapak. 


\section{Journal of Software Engineering Ampera}

Vol. 1, No. 3, October 2020 e-ISSN: 2775-2488

https://journal-computing.org/index.php/journal-sea/index

3) Variabel interaksi pelayanan (interaction quality) berpengaruh negatif terhadap kepuasan pengguna website e-commerce Bukalapak.

\section{DAFTAR PUSTAKA}

Abdillh, \& L.A. (2017). The role of big data and cloud computing for technology based business. Paper presented at the The First International Conference on Education and Technology .

Barnes, S., \& Vidgen, R. (2002). An integrtive approach to the assessment of ecommerce quality. 114-127.

“Barnes, S., \& Vidgen, R. (2003). Measuring web site quaity improvements : a case study of the forum on strategic management knowledge exchange. Industrial management \& Data systems 103,5 , 297-309".

Ghozali, I. (2012). Aplikasi Analisis Multivariate dengan program IBM SPSS.

Hastanti, R., \& Purnama, B. (2015). Sistem penjualan berbasis web (ecommerce) pada tata distro kabupaten pacitan. Bianglala Informatika 3,2 .

Santoso, S. (2010). STATISTIK PARAMETRIK Konsep dan Aplikasi Dengan SPSS.

Sugiyono. (2017). Metode Penelitian Pendidian Kuantitaf dan Kualitatif r\&d,

Sugiyono. (2014). Statistika untuk Penelitian.

SUPARDI. (2014). Statistik Penelitan Pendidikan. Cv Alfabeta.

Wijaya, T. (2009). Analisis Multivariat: Teknik Olah Data untuk Skripsi, Tesis, dan Disertasi Menggunakan SPSS. 